\title{
Escritura e Imagen
}

ISSN: $1885-5687$

\section{La tragedia hölderliniana y su correlato plástico: la obra pictórica de C. D. Friedrich}

\author{
Mikel Martínez Ciriero ${ }^{1}$
}

Recibido: 16-11-2020 / Aceptado: 30-04-2021

Resumen: El presente artículo profundiza en los escritos teóricos de Friedrich Hölderlin sobre la tragedia y lo trágico, interpretándolos a la luz de su obra trágica inconclusa La muerte de Empédocles. Posteriormente, la reflexión de Hölderlin es puesta en relación con la obra del pintor Caspar David Friedrich, descrita como "tragedia del paisaje". El estudio comparado de literatura y pintura, acompañado por la propia reflexión de ambos artistas, ofrece la oportunidad de abordar desde una perspectiva múltiple ciertas características de las subjetividades representadas por el poeta y el pintor, cuya existencia aparece ligada a un profundo sentimiento trágico. Palabra, imagen y reflexión romántica emergen en este diálogo entre Hölderlin y Friedrich para ofrecer una fecunda clave de lectura a partir de lo trágico, tanto en su dimensión artística, como vivencial.

Palabras clave: F. Hölderlin; literatura filosófica; C. D. Friedrich; pintura filosófica, subjetividad, tragedia; romanticismo alemán.

\section{[en] The Hölderlinian tragedy and its plastic correlate: the pictorial ouvre of C. D. Friedrich}

\begin{abstract}
This article delves into Friedrich Hölderlin's theoretical writings on tragedy and the tragic, interpreting them in the light of his unfinished tragic work The Death of Empedocles. Subsequently, Hölderlin's reflection is related to the work of the painter Caspar David Friedrich, described as "tragedy of the landscape". The comparative study of literature and painting, accompanied by both artists' own reflections, offers the opportunity to approach from a multiple perspective certain characteristics of the subjectivities represented by the poet and the painter, whose existence appears to be linked to a deep sense of tragedy. Word, image and romantic reflection emerge in this dialogue between the poet and the painter to offer a fertile key to reading the tragic in both its artistic and experiential dimensions.

Keywords: F. Hölderlin; philosophical literature; C. D. Friedrich; philosophical painting; subjectivity; tragedy; German Romanticism.
\end{abstract}

Sumario: 1. Introducción; 2. Reflexión y creación en Hölderlin: escritos sobre la tragedia y las versiones de La muerte de Empédocles; 3. La imagen trágica: C. D. Friedrich representa el silencio, la melancolía y la muerte; 4. Conclusión; 5. Referencias bibliográficas.

Cómo citar: Martínez Ciriero, M. (2021) "La tragedia hölderliniana y su correlato plástico: la obra pictórica de C. D. Friedrich”, en Escritura e Imagen 17, 47-67.

11mikciraz@gmail.com 


\section{Introducción}

La relevancia filosófica de Friedrich Hölderlin ha alcanzado un cierto estado fuera de toda duda desde que fuera puesto en valor en el siglo XX. Lejos queda la sombra de la locura que parecía contaminar buena parte de sus reflexiones. La literatura de Hölderlin es esencialmente filosófica -así lo atestigua por ejemplo su novela, Hiperión o el eremita en Grecia-, pero el poeta alemán legó a su vez una serie de escritos teóricos sobre muy diversos temas, entre los que destaca por extensión e intensidad su reflexión sobre la tragedia. Dicha reflexión incluye textos sobre la tragedia clásica, concretamente sobre la Antígona y el Edipo de Sófocles. Asimismo, el poeta reflexiona sobre el carácter del género trágico y las posibilidades que este alberga. La riqueza de estos escritos se revela de modo particular a la luz de las tres versiones que su autor realizó sobre la muerte de Empédocles de Acragante. Ello se debe a que la pretensión subyacente a dicha tragedia, de corte romántico e idealista, era dar forma literaria a las reflexiones teóricas vertidas previamente por el autor, tal y como muestra su texto Fundamento para el Empédocles. De este modo, la ardua y en ocasiones oscura reflexión hölderliniana es susceptible de ser iluminada a través de su realización práctica en La muerte de Empédocles.

Sin embargo, ni la reflexión sobre la tragedia ni la representación de carácter trágico son patrimonio exclusivo de Hölderlin. De hecho, el Romanticismo está atravesado y alimentado por un fecundo espíritu trágico ${ }^{2}$. Si bien Hölderlin es el paladín literario de dicho espíritu, C. D. Friedrich lo es en la pintura ${ }^{3}$. La obra de Friedrich, pintor destacado del Romanticismo alemán, guarda una especial afinidad con el corpus hölderliniano debido al uso simbólico que ambos hacen de ciertas experiencias vitales, ligadas a un espíritu melancólico y profundamente trágico. La obra plástica de Friedrich ofrece así una visión complementaria y potenciadora de las reflexiones románticas en torno a la tragedia y el sujeto trágico vertidas por Friedrich Hölderlin en sus ensayos, favoreciendo la comprensión de dicha reflexión. De este modo, imagen y palabra permiten profundizar en una subjetividad en conflicto y tensión, la del creador genial que es al mismo tiempo artífice y protagonista de la obra artística en el Romanticismo.

\section{Reflexión y creación en Hölderlin: escritos sobre la tragedia y las versiones de La muerte de Empédocles}

La tragedia fue para Hölderlin un motivo extenso de reflexión y labor poética, comenzando por las tres versiones inacabadas de la tragedia inspirada en Empédocles de Acragante, a lo que habría que añadir sus dos traducciones del Edipo y la Antígona de Sófocles. Hay que precisar que no resulta en absoluto fácil hacerse cargo de la reflexión del poeta-filósofo alemán sobre la tragedia debido a la oscuridad de sus escritos teóricos ${ }^{4}$, pero trataré de ofrecer una clave explicativa de carácter general a

2 El Romanticismo estaría atravesado por "una concepción del mundo, nueva y revolucionaria, centrada en la conciencia, diversamente manifestada, de la irresoluble condición trágica del hombre moderno". Cfr. Argullol, R., El Héroe y el Único, Barcelona, Acantilado, 2008, p. 18.

3 Cfr. Argullol, R., La atracción del abismo. Un itinerario por el paisaje romántico, Barcelona, Acantilado, 2006 y Argullol, R., El Héroe y el Único, op. cit.

4 Los escritos teóricos de Hölderlin están recogidos en Hölderlin, F., Ensayos, Madrid, Hiperión, 2017. Me 
la luz de las versiones del Empédocles. Gracias a esta realización literaria particular resulta posible reunir las piezas de esta intrincada constelación teórica acerca de la tragedia, en la que Hölderlin se esforzaba por actualizar la esencia trágica contenida en la obra de Sófocles. Dicho esfuerzo está contenido en la caterva de escritos legados por Hölderlin, especialmente aquel en el que describe el germen filosófico de $L a$ muerte de Empédocles. El Fundamento para el Empédocles permitirá ir poniendo en relación las reflexiones del poeta con su realización práctica.

La concepción hölderliniana del género trágico solo es susceptible de ser entendida a partir del clima intelectual generado por el Idealismo y el Romanticismo. Dicho clima intenta preservar la tragedia antigua conservando su forma ${ }^{5}$, pero utilizando un contenido moderno ${ }^{6}$ fuertemente influenciado por la dialéctica idealista. La poesía trágica y la reflexión de Hölderlin en torno a ella ha de entenderse como una continuación de la reflexión-poesía de Hölderlin, cuyo marco sería la relación entre el individuo -el genio poético particularmente- y la naturaleza/divinidad, es decir, la relación de oposición entre lo finito e infinito, objetivo y subjetivo. Dentro de la literatura filosófica cultivada por el poeta, la tragedia fundaría su posibilidad de significación en la paradoja según Hölderlin, una paradoja de la que brota lo originario: el "fondo oculto de toda naturaleza" . Expresado en términos del propio Hölderlin, el "Ser absoluto" es intuido ${ }^{8}$ en el conflicto que contiene la poesía trágica.

Esta relación constitutiva entre la tragedia y la intuición intelectual mueve a Hölderlin a considerar que la tragedia es el género poético dotado de una mayor universalidad. Dicho vínculo ha de entenderse a la luz de la esencia de lo trágico: la capacidad de lo trágico de albergar en sí y desplegar las oposiciones en su carácter conflictivo e irreconciliable es lo que permite al poema trágico convertirse en metáfora de la intuición intelectual. Esta intuición intelectual consiste en sentir la "unidad con todo lo que vive", una unidad de la que no es posible disponer, pero que sí que puede ser aprehendida momentáneamente en medio de la pugna entre las diversas oposiciones. Esta intuición permite sentir en la lucha entre lo material-separado y lo

centraré principalmente en Sobre los diferentes modos de poesía, Sobre la distinción de los géneros poéticos, La significación de las tragedias, Fundamento para el Empédocles, Notas sobre Edipo y Notas sobre Antígona.

5 Hölderlin llevará esta preservación formal hasta sus últimas consecuencias en sus traducciones de Edipo y Antígona. El tratamiento de estas traducciones, o más bien "versiones", excede las posibilidades del presente trabajo. En ellas Hölderlin aborda mediante una aproximación extremadamente moderna del lenguaje y la traducción la imposibilidad de recuperar la experiencia griega original de la tragedia -tras la imposibilidad de finalizar satisfactoriamente La muerte de Empédocles después de tres intentos frustrados-, tal y como se describe en los estudios introductorios de las ediciones recogidas en la bibliografía a cargo de H. Cortés y A. Leyte.

6 Garelli, G. y Gentilli C., Lo trágico, Madrid, Machado, 2015, p. 54. Hölderlin expresa en una carta qué sería lo específico de la tragedia moderna: "esto sí que es lo trágico entre nosotros, que nos vayamos del reino de los vivos calladamente, metidos dentro de una caja cualquiera, y no que destrozados por las llamas paguemos por el fuego que no supimos dominar" Hölderlin, F., Correspondencia completa, Madrid, Hiperión, 1990, pp. 545546.

$7 \quad$ Significación de las tragedias en Hölderlin, F., Ensayos, op. cit., p. 93.

8 Hölderlin concibió la intuición intelectual como el medio con el que superar toda escisión, incluida aquella que introducía según el poeta la doctrina fichteana del "Yo" y el "no-Yo". Hölderlin recurre a una unidad previa al Yo fichteano, distinguiendo el ser de la identidad -"Yo=Yo"- del "Ser absoluto". La separación originaria (Urteilung) entre sujeto y objeto aparecería propiamente con el juicio (Urteil), distinguiendo el ser del "Yo" que presupone un estado escindido de aquel "Ser" originario sin fractura alguna. La intuición intelectual sería la posibilidad de aprehender el "Ser absoluto" y conocer dicho estado previo a toda escisión ontológica. Cfr. el texto de Hölderlin Juicio y ser, recogido en Ibidem, pp. 27-28.

$9 \quad$ Sobre la distinción de los géneros poéticos, en Ibidem, p. 85. 
ligado-permanente que lo uno y lo otro forman parte de un estado primigenio, de un "estado de lo originariamente unitario" 10 que se ha fracturado irremediablemente ${ }^{11}$ en una doble fuerza formadora e informe.

Dicha doble fuerza estaría representada respectivamente por el arte y la naturaleza. Arte y naturaleza se contraponen, pero dependen el uno de la otra, porque el arte es la "flor, el cumplimiento de la naturaleza" y solo mediante la vinculación de la naturaleza con el arte esta se hace propiamente divina. Estas dos realidades responden en Hölderlin a las categorías de lo orgánico y lo orgiástico ${ }^{12}$ : lo orgánico, el hombre y el arte, tiene que ver con la formación; lo aórgico es lo universal e infinito. Uno y otro se hallan inmersos en una relación de influencia recíproca y dependencia mutua: la naturaleza tiende a la organicidad y a la particularización; el hombre a la aorgicidad, a lo ideal e infinito. Mantienen entre sí una relación de fuerzas, una lucha en la que aparece un cierto equilibrio y armonía. En dicho estado de fuerzas que se contraponen podemos alcanzar un sentimiento íntimo de unificación en el que según Hölderlin lo divino se presenta de forma sensible. Posteriormente, cuando ese sentimiento se ha disuelto, disponemos de dicho momento de reunificación de un modo más claro y universal. Es decir, podemos introducirnos en esa relación de fuerzas y retrotraernos idealmente al momento previo a la fractura. Podemos sentirlo y posteriormente conocerlo.

Lo trágico radica en ese momento de unificación en que naturaleza e intimidad del hombre se hacen Uno, y "el ilimitado hacerse Uno se purifica mediante ilimitada escisión"13: la oposición de la unificación infinita con la escisión infinita daría lugar a la purificación característica de la tragedia, la catarsis recogida por Aristóteles en su Poética (IV 1149b). Sin embargo, si el objetivo de la catarsis aristotélica puede describirse como un modo de resolver el caos en la forma ${ }^{14}$, Hölderlin parece no querer llevar a cabo resolución alguna en la medida que mantiene la tensión entre formado e informe, orgánico y orgiástico, en una influencia mutua e inagotable. La tragedia y lo trágico son contaminados por la dialéctica idealista al adoptar ese carácter procesual, permitiendo transmutar el sentimiento trágico en un estado anímico más o menos permanente, en condición existencial.

La influencia idealista se ve complementada por un elemento claramente romántico: el genio poético es el engranaje central de la maquinaria literaria trágica. El protagonismo del poeta en el género trágico se debe a su especial naturaleza de carácter profético y sacerdotal, descrita por Hölderlin en su novela Hiperión. La naturaleza de Hiperión y de aquellos poetas que se han hecho con el "espíritu poético"15 es la de un nexo que media entre dos extremos - conecta y comunica la

\section{Ibidem.}

11 Hölderlin evoca aquí a Plotino y el Uno que se derrama necesariamente: "un estado de lo originariamente unitario, en el cual ello se encuentra por cuanto ello tiene que salir de sí por mor de la detención" Ibidem.

12 Lo orgánico se vincularía a esencia y conciencia, actividad autónoma, arte y reflexión, lo formado y particular. Lo aórgico se relaciona con: naturaleza, ilimitado, inconcebible, no-sentible, informe, infinito. Estas dos fuerzas recuerdan al "Amor" y "Odio" de Empédocles, y precontienen en cierto modo lo apolíneo y dionisiaco nietzscheanos.

13 Notas sobre Edipo, en Ibidem, p. 148.

14 Garelli, G. y Gentilli C., Lo trágico, op. cit., p. 104.

15 El poeta, el sujeto genial romántico, ha de asimilar la manera de proceder del "espíritu poético" para poder crear de modo acorde a dicho espíritu, en comunión con lo vivo. Solo así puede su arte contribuir a la pedagogía del pueblo y adquirir un carácter profético. Sobre el modo de proceder del espíritu poético, en Hölderlin, F., Ensayos, op. cit., p. 58. 
esfera divina con la mortal-y aspira a lo más excelso: la reunificación con lo divino. El creador (poietés) adquiere con Hölderlin una categoría superior a la mortal con el riesgo de obtener una naturaleza ni plenamente divina ni humana, sino la de una quimera, un ser obligado a tratar de representar en su finitud la infinitud de la que es testigo. Debido al carácter quimérico de su naturaleza, así como a la mediación que lleva a cabo entre lo mortal y lo divino, el poeta se halla ligado a lo trágico en Hölderlin, tal y como expresará a través de las versiones inconclusas de su tragedia La muerte de Empédocles.

La constitución quimérica del poeta lo convierten en el material poético perfecto en el que contener la paradoja o el trágico e irreconciliable desgarro. Será la figura de Empédocles de Acragante la escogida por Hölderlin para dar cuerpo a su teoría sobre la tragedia. Hölderlin explica que lo "orgánico" y lo "aórgico" se invierten y unifican en este hombre "tan íntimamente que en él se hacen Uno"16. Empédocles es mortal, pero al mismo tiempo parece poseer una tendencia natural hacia lo "aórgico", pues en la medida que tiene relación -verbal, sensible e intelectual- con la divinidad es capaz de comunicarse con la naturaleza e incluso transformarla. Su poesía es aórgica pues guarda una fuerza creadora igual a la de la naturaleza; su palabra es canto de lo divino, pero también es una manifestación lingüística, positiva y particular. En palabras de Hölderlin, lo subjetivo es más objetivo en él, y lo mismo sucede en sentido contrario ${ }^{17}$, reproduciendo una unificación demasiado íntima entre los extremos, una unificación trágica en la que "lo monstruoso, como el-dios-y-elhombre se aparea" 18 .

Empédocles es caracterizado en las versiones de Hölderlin como un individuo superior, libre en cierto modo de necesidades mortales gracias a que vive en un estado de armonía y compenetración con el mundo natural, donde se siente como un "dios en sus elementos"19. Sin embargo, esa superioridad no elimina la distancia que lo separa efectivamente de los dioses, pues no deja de ser un ser humano. Esta distancia insalvable, unida a su naturaleza quimérica, termina por engendrar en él una ambición prometeica que provoca su ruina. Empédocles se deja llevar por el orgullo y trata de someter soberbiamente a la naturaleza para convertirse así en su dueño, quebrando la relación de armonía y amor con el mundo natural, una falta que le lleva a la expulsión de la comunidad con lo divino. Tras proclamarse a sí mismo como un $\operatorname{dios}^{20}$ en un acto de individualización que no le corresponde en su carácter

Fundamento para el Empédocles, en Ibidem p. 112.

17 Un ejemplo de esta inversión sería el papel del sueño, que aparece en varias ocasiones en las versiones del Empédocles. El poeta siciliano llega a preguntarse si su contacto con lo divino ha sido un sueño (los lectores nos incorporamos cuando la conexión ha desaparecido y ello contribuye a crear la duda), y otros personajes de la tragedia se refieren al potencial creador del sueño de Empédocles, llegando a afirmar "Ser él mismo, eso sí es la vida, y los demás sólo somos su sueño" Hölderlin, F., La muerte de Empédocles, Barcelona, Acantilado, 2001, p. 13. En Hiperión leemos que "[e]l hombre es un dios cuando sueña y un mendigo cuando reflexiona", Hölderlin, F., Hiperión o el eremita en Grecia, Madrid, Hiperión, 2017, p. 26. Para una reflexión más desarrollada a este respecto, cfr. Argullol, R, La atracción del abismo. Un itinerario por el paisaje romántico, op. cit., pp. 63 y ss. Aquí Argullol destaca la importancia del elemento onírico en el Romanticismo, relacionado con una vuelta hacia el inconsciente y como claro antecedente del papel desempeñado por el sueño y los recovecos ocultos de la conciencia tanto en el arte como en la filosofía del siglo XX, especialmente en el surrealismo y el psicoanálisis.

18 Notas sobre Edipo, en Hölderlin, F., Ensayos, op. cit., p. 148

19 Hölderlin, F., La muerte de Empédocles, op. cit., pp. 12-13.

20 "Te he despreciado y me he considerado/yo solo el dueño [...] Los dioses se habían puesto a mi servicio, yo era el único/dios, y así lo proclamé con orgullo atrevido" Ibidem, p. 32. 
de Uno -en el que lo orgánico y aórgico se habían unificado- se enfrenta como castigo a la nada, frente a la vivencia de lo sagrado que lo había acompañado hasta entonces. Este es el castigo (Nemesis) que recibe ante su acto de desmesura (hybris): su titánica ambición por el Todo se trueca en íntima experiencia de una "desolación sin límites"21.

Los dioses lo condenan al ostracismo, cifrado en el silencio de la naturaleza. Empédocles cesa de percibir el sonido armónico de la naturaleza: solo queda un silencio pesado y asfixiante, que se opone a un pasado inundado por la música armónica y consonante de la divina naturaleza. La tragedia de Empédocles es la del silencio, sensación que confirma vía sensible su expulsión del espíritu del mundo con el que había convivido toda su vida:

¡Si pudiera, tan solo una vez más, ante mi alma evocarlos,/para que mi pecho mudo, que la muerte devasta,/resonara con todos sus sonidos!/¿Lo soy aún? ¡Oh vida! ¿Oí el murmullo/de todas tus aladas melodías, y escuché/tu antigua consonancia, oh gran naturaleza? [...]/El amor muere al escapar los dioses,/bien lo sabes. ${ }^{22}$

El silencio y el sonido o la música aparecen relacionados con la comunión y armonía, como una metáfora del ya metafórico Eros presente en la obra de Hölderlin. Silencio y música son además condicionantes de la naturaleza del poeta, pues solo aquel que escuche las melodías y consonancias naturales podrá cantarlas, es decir, reproducir mediante su palabra el espíritu de la naturaleza y la divinidad, logrando dar forma al mundo, transformarlo en virtud de ese estado de sensible comunión con el mundo natural.

Esa capacidad poética es vehiculada por un lenguaje que es, a su vez, adecuado a la naturaleza de Empédocles, una naturaleza de amor y comunión con lo divino. El lenguaje poético guarda en Hölderlin una relación esencial con lo bello y el amor: es capaz de interpelar a las diversas facultades humanas -incluyendo al entendimiento, pero no solo a él-mediante una armónica configuración, a diferencia de disciplinas como la filosofía, dependiente exclusivamente del intelecto. La importancia del verbo es radical en la obra de Hölderlin, en esa línea de la valorización del lenguaje llevada a cabo en el Romanticismo. Es particularmente relevante en Empédocles, porque la palabra trágica es descrita por Hölderlin como "mortalmente fáctica" 23 en sus Notas sobre Antígona, es decir, la palabra trágica posee la virtualidad de conducir a la muerte. Así sucede con Empédocles, quien se condena a sí mismo profiriendo la "audaz palabra"24 _“¿Por una palabra? Sí. Y que me reduzcan/los dioses a la nada, como antes/me amaron" ${ }^{25}$ - Tal es el poder del verbo, capaz de provocar la caída de un ser excelso y conducirlo hasta su muerte.

Ante este ostracismo y aislamiento, lo trágico de la situación de Empédocles reside en que su naturaleza sigue siendo esencialmente la de creador, pero su canto ha quedado privado de su fuente, en la medida que poeta y poesía han sido desgarrados de lo sagrado. Frente a esta tesitura, el poeta buscará el medio de volver a la naturaleza y la solución será la ascensión al Etna y el suicidio, una autoaniquilación absoluta que

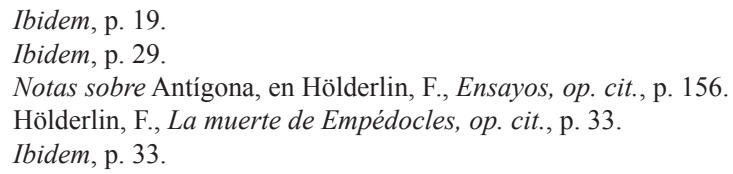


no dejará traza material alguna ${ }^{26}$. El individuo se disuelve por la fuerza del magma volcánico y la disolución se consuma de forma literal, material y formalmente. Así, Empédocles logra liberarse de todo carácter finito y limitado y se une a la totalidad, a la naturaleza. Su ambición por dominar el fuego prometeico es trocada por la resolución de fundirse con él.

Empédocles ofrece su dolor y su aniquilación como últimos y consumados materia y acto creadores: el sufrimiento presente en la tragedia y la muerte -la consumación de lo trágico- obtienen así una dimensión creadora. La muerte que engendra vida, tema que atraviesa el Romanticismo, comparece de este modo en la obra de Hölderlin:

Cercana, cada vez/más cercana está mi hora, y del barranco/sube ya el mensajero familiar de mi noche,/el viento nocturno, mensajero de amor. [...] ¡Oh! Si tan fácil te resultó la vida,/_fue para que hallaras todos los goces del denominador/en una sola acción llena de plenitud?/ [...] Ahora, la noche envolverá en un instante/de sombras mi cabeza. Pero brota jubilosa/la llama de mi pecho denodado. ¡Estos deseos/estremecidos! ¿Qué? ¿Es que, en la muerte,/se me enciende, al fin, la vida? ${ }^{27}$

Hölderlin reflexiona sobre este tema eminentemente romántico en su texto El devenir en el perecer ${ }^{28}$, donde explica que el lenguaje trágico dispone de "lo perpetuamente creador" gracias a su vinculación con la disolución, ese tránsito que se halla entre el ser y el no-ser. Esta disolución o proceso que se observa en el mundo natural, en el que la corrupción y la generación son omnipresentes, nos conduciría a conceptualizar el acto reproductivo por el que la vida se disuelve constantemente en cada elemento y se reproduce en el siguiente. De este modo se produciría en nosotros un sentimiento del perecer que permite intuir aquello primero y originario que se disuelve. Aplicado a la tragedia, dado que esta funda su significado sobre la paradoja y los opuestos, el lenguaje trágico da lugar a una pugna incesante, es decir, de ello nace una creación perpetua a raíz de la vivificación de "lo incomprehensible, lo infeliz de la disolución misma y de la lucha misma de la muerte, mediante lo armónico, comprehensible, viviente" 29 . En la disolución y en la tragedia vida y muerte se unifican en la medida en que establecen una relación recíproca sin final aparente.

El devenir de Empédocles no es otro que el perecer. El destino de Empédocles ${ }^{30}$, instancia de aquella aspiración del sujeto romántico hacia la excelsitud, está abocado irremediablemente a la tragedia, a un "holocausto" en el que el poeta se disuelva, pues la unificación finita que él encarna tiene como único desenlace posible la disolución. Este desenlace es requerido por la tragedia y su efecto catártico, pero también lo es por el carácter de Empédocles. Solo así podemos experimentar la purificación

26 Diógenes Laercio describe cómo Empédocles desapareció una noche, y con el tiempo sólo encontraron una de sus sandalias junto al cráter del Etna. Cfr. Waterfield, R., The first philosophers. The presocratics and the sophists, New York, Oxford University Press, 2000, p. 13.

27 Hölderlin, F., La muerte de Empédocles, op. cit., p. 112.

28 Hölderlin, F., Ensayos, op. cit., pp. 101-107.

29 El devenir en el perecer, en Ibidem, p. 102.

$30 \quad$ El destino es un tema recurrente en el Romanticismo y en la obra de Hölderlin. La insatisfacción permanente que provoca perseguir la meta más alta conducirá a Empédocles al suicidio, como corresponde al género trágico y su efecto purificador o catártico. 
de lo trágico, radicalmente diferente al papel de Bildung que cumple el Hiperión de Hölderlin mediante el desarrollo dialéctico de la conciencia al que conducen las epístolas de la novela. Es interesante comparar esta tragedia con el Hiperión, porque en su relación salen a la luz reflexiones sobre la subjetividad y la creación literaria. En el caso de Hiperión estamos ante una novela en la que Hölderlin se identifica en buena medida con su personaje principal: Hölderlin e Hiperión serían dos caras de un mismo yo; por un lado estaría el origen, y por otro la elaboración ideal y poética a partir de esa fuente subjetiva y experiencial. No es así en el caso de Empédocles, lo cual está directamente relacionado con el hecho de que sea protagonista de una tragedia.

La tragedia es para Hölderlin, como ya hemos dicho, metáfora de una intuición intelectual. Para que esta sea efectiva, si bien la tragedia parte como otros géneros poéticos de la intimidad del artista, aquí se debe conseguir un elemento ajeno al poeta y su experiencia, pero que sea análogo y pueda contener dicha intimidad. La fuente del poema trágico sigue siendo la intimidad del autor, pero hay que decir que tanto el poeta como su experiencia no protagonizan el poema, únicamente lo fundamentan. Hölderlin explica cómo ha de realizarse una exteriorización y negación de dicha intimidad a partir de ese fundamento, para acercarla posteriormente a lo simbólico mediante este continente análogo universalizador y externo. La intimidad sería solo el fundamento desde el que aproximarse al nefas, dotando dicha intimidad del mayor grado posible de infinitud e inexpresabilidad:

el poeta trágico, por cuanto expresa la intimidad más profunda, niega por completo su persona, su subjetividad, incluso el objeto presente a él; transfiere todo eso a una personalidad extraña, a una objetividad. ${ }^{31}$

Este continente poético y formal es Empédocles, escogido por Hölderlin seguramente debido a su afinidad con el pensamiento místico y críptico del poetafilósofo-sacerdote siciliano ${ }^{32}$. La subjetividad no es vertida directamente sobre el poema trágico, sino que es reelaborada según ese elemento externo, pero, pese a la intención universal y simbólica, las conexiones entre Hölderlin y la tragedia son claras, y también lo son entre el Empédocles y el Hiperión ${ }^{33}$. No en vano, la novela de Hölderlin es una representación de su propia persona, y por ello es fácil encontrar las conexiones entre Hiperión y el resto de la obra del poeta. Concretamente, hay un fragmento del Hiperión que parece precontener el germen de la tragedia de Empédocles prácticamente en su totalidad:

Hay un callar, un olvido de toda existencia en que es como si hubiéramos perdido todo [...]. Tranquilo y solitario, miraba ante mí, sin volver la vista ni al pasado ni al futuro.

31 Fundamento para el Empédocles, en Hölderlin, F., Ensayos, op. cit., p. 109.

32 Hölderlin conocía los escritos de Empédocles y también fuentes biográficas sobre el mismo. La incorporación de Pantea o Pausanias como personajes de sus versiones de la tragedia serían un ejemplo de esto último. Respecto al pensamiento del griego, encontramos en la reflexión de Hölderlin resonancias que tienen que ver con esa concepción dinámica y eterna de la naturaleza regida por una doble fuerza, el Amor y el Odio. Cabe añadir además el carácter poético y sacerdotal, también filosófico, de Empédocles. Cfr. Bernabé, A., Fragmentos presocráticos, Madrid, Abada, 2019, pp. 294 y ss.

33 Además de las obvias, como las dos menciones del Etna-e, implícitamente, de Empédocles- en recogidas en el Hiperión, Hölderlin, F., Hiperión o el eremita en Grecia, op. cit., pp. 36, 202. 
Las cosas, lejanas o próximas, ya no penetraban en mi espíritu; a los hombres, cuando no me obligaban a mirarlos, no los veía. [...] Ya no decía nunca más a la flor: ¡tú eres mi hermana!, ni a las fuentes: ¡somos de la misma raza!, sino que daba a cada cosa fielmente su nombre, como un eco [...] corría ante mí el mundo desprovisto de toda belleza. [...] Nada puede crecer y nada puede hundirse tan profundamente como el hombre. A menudo se compara su sufrimiento con la noche del abismo y su felicidad con el Éter. ${ }^{34}$

En este fragmento, Hiperión/Hölderlin se halla en un estado de soledad y desconexión respecto a la naturaleza y la divinidad que le impide proferir la palabra poética, nombrando a cada cosa por su nombre. El lenguaje poético desaparece cuando la conexión viva con la belleza es cercenada y con ello la capacidad creadora; solo queda el lenguaje corriente y conceptual, con su carácter disecador. Hiperión siente aquí cómo la naturaleza no responde a su llamada, cayendo desde el "Eter" hacia el "abismo", una caída cuya consumación en las profundidades de la tierra representa Empédocles. El exceso, sea por la ambición desmesurada que lo alimenta o por el desenlace al que conduce - la rendición ante el abismo--, es la senda hacia la ruina, tal y como queda expresado en el trágico desenlace de Empédocles. Tras recibir un amor excesivo por parte de los dioses y disponer de una existencia excesivamente bella, la vida de Empédocles termina con un acto creador sui generis y deja de ser bella, para ser sublime ${ }^{35}$ :

¡Oh, por los bienaventurados! No condenes/al ser glorioso, cuyo honor/se convirtió en desdicha, al que debe morir/porque su vida fue excesivamente bella,/porque todos los dioses le amaron demasiado. [...] El que es infinito, todo lo recibe infinitamente ${ }^{36}$.

En definitiva, la reflexión hölderliniana sobre la tragedia y lo trágico se halla condicionada por el clima idealista en el que se gesta, fundando su posibilidad sobre un estado primigenio de unión y comunión que se ha quebrado y ha dado lugar a dos fuerzas opuestas. El poeta es capaz de aprehender fugazmente dicho estado originario mediante la intuición intelectual, logrando atisbar el "Ser absoluto". Así, el genio poético puede trasladar esta particular pugna entre lo "orgánico" y "aórgico" a un continente literario, y crear una obra poética de carácter universal -la tragediaen la que representar dichas oposiciones. La muerte de Empédocles haría partícipe al lector de todo ello mediante la situación a la que se enfrenta su protagonista: tras ser expulsado de su estado poético en comunión con las fuerzas divinas, Empédocles decide ofrecer su vida a la totalidad con el objetivo de purgar su desmesura (hybris). Esta obra de Hölderlin, además de dar cuerpo a sus reflexiones sobre la tragedia, muestra la relevancia del sujeto romántico, la importancia capital del poeta genial capaz de aprehender el "espíritu poético" y su devenir. La subjetividad del genio romántico es absolutamente protagonista en los escritos de Hölderlin, teóricos y literarios: si bien esta subjetividad es elaborada idealmente y reafirmada en Hiperión, en el Empédocles se observa, por un lado, la negación de la subjetividad del autor

$34 \quad$ Ibidem, p. 67.

35 Hölderlin menciona en una carta cuya cronología coincide con las redacciones del Empédocles una serie muy sugerente de intereses: una elaboración dramática de la muerte de Sócrates y un trabajo sobre el Fedro en el que aparecerían también reflexiones en torno a lo bello y lo sublime en Kant y Schiller. Cfr. Hölderlin, F., Correspondencia completa, op. cit., pp. 208-212.

36 Hölderlin, F., La muerte de Empédocles, op. cit., p. 118. 
como requisito teórico de la obra literaria y, por otro lado, la sublime aniquilación de la subjetividad protagonista. El conflicto ontológico captado por el poeta y filósofo romántico le lleva a adoptar un papel de profeta y educador, pero también le mueve hacia una disolución que le permitiría resolver dicha oposición y con ello consumar su sentimiento trágico.

\section{La imagen trágica: C. D. Friedrich representa el silencio, la melancolía y la muerte}

La reflexión de Hölderlin sobre el aspecto más trágico del artista romántico, en conexión con la relación de este con la naturaleza y lo divino, encuentra una sugerente representación plástica en la obra de C. D. Friedrich. Esto sucede de forma acusada en una selección de obras del pintor alemán, como desarrollaremos más adelante. Dichas obras presentan una afinidad temática con la vertiente trágica de las reflexiones hölderlinianas, a saber, las materializadas en La muerte de Empédocles y analizadas en este trabajo. Sin embargo, antes que su Empédocles, el Hiperión hölderliniano también había experimentado un cierto sentimiento trágico ligado a la vivencia de la nada y la melancolía. Si bien son la totalidad y la belleza los protagonistas del Hiperión $^{37}$, la novela de Hölderlin contiene un cierto germen nihilista. Este viene representado por una serie de reflexiones y sentimientos realmente oscuros, en los que Hiperión expresa un nihilismo que atraviesa al ser humano moderno, en contraposición con aquel de la Antigüedad. En estas ocasiones lo único que advierte Hiperión en la contemplación de la vida y en la elevación espiritual es la nada más absoluta, un desierto que no es sino proyección de su vacío interior:

A veces, sin embargo, se dejaba sentir todavía en mí una fuerza espiritual, aunque sólo con afanes de destrucción. [...] Cuando contemplo la vida, ¿qué es lo último de todo? Nada. Cuando me elevo en el espíritu, ¿qué es lo más elevado de todo? Nada. [...] Si sobre ti y ante ti no encuentras más que el vacío y el desierto, es porque en tu interior no hay más que vacío y desierto. ${ }^{38}$

37 La totalidad hay que entenderla en Hölderlin como un Todo de carácter panteísta, representado mediante la naturaleza. La relación del individuo con este medio natural es al mismo tiempo su relación con la totalidad, la relación entre lo finito y lo infinito. La belleza sería la instancia sensible del Todo, el medio sensible con el que resulta posible captar el Todo y acceder a él. De ahí la suma importancia del poeta, capaz de atisbar dicha belleza y de trasladarla a su obra poética.

38 Hölderlin, F., Hiperión o el eremita en Grecia, op. cit., pp. 70-72. 


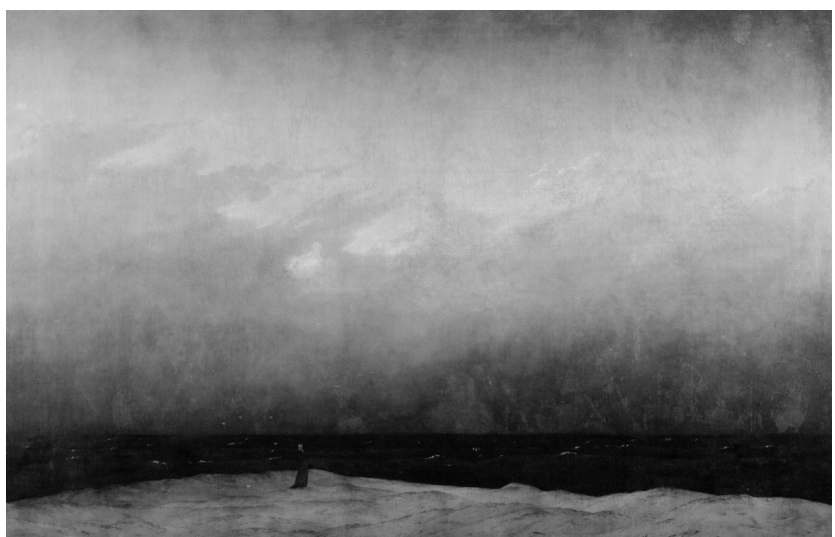

C. D. Friedrich, Monje a la orilla del mar $(1808-1810)^{39}$

Tanto el vacío como el desierto evocan imágenes de la muerte y la desolación extendiéndose de forma ilimitada, causando una profunda y terrorífica melancolía se ha citado más arriba la "desolación sin límites" que sentía Empédocles-. Todo ello pertenece al sentimiento de lo sublime, tematizado y desarrollado conceptualmente por E. Burke e I. Kant. Este último ligó lo sublime a la noche, a la tragedia y al carácter melancólico ${ }^{40}$, mientras que el teórico inglés ofrecía una enumeración de elementos que favorecen la conjura de este sentimiento: el sufrimiento, el temor, la oscuridad, la infinitud o la vastedad ${ }^{41}$. Todo ello será asimilado como parte esencial del Romanticismo, en la medida que la nueva sensibilidad romántica y sus conflictos conceptuales encuentran en esta categoría estética toda una serie de posibilidades representativas.

Efectivamente, el sentimiento de lo sublime fue central en el Romanticismo, pues aglutinaba toda esa vertiente oscura, dionisiaca y pasional de la sensibilidad romántica. Esta categoría estética se vincula a la dimensión creativa de la muerte y la visión 'positiva' del sufrimiento, así como a la disolución provocada por el exceso sensible de lo sublime. Este sentimiento es excesivo en la medida que nos desborda, frente al agrado y equilibrio que desprende lo bello. La condición humana desgarrada, presente en parte del Romanticismo, encuentra en lo sublime una posibilidad de representar el "Éter" y el "Abismo", el caos y la infinitud, espacios en los que propiamente lo finito no tiene cabida. El individuo romántico siente el Todo, pero también la Nada, y su intención es encarnar ambos extremos en su literatura y pintura, así como los procesos sensibles e intelectuales que desencadenan dichos extremos.

Hölderlin vincula lo sublime con su obra trágica, como hemos podido observar. Tomando prestadas sus nociones, diremos que la categoría estética de lo sublime permite sentir ese momento en el que lo "aórgico" y lo "orgánico" colisionan: el individuo siente momentáneamente cómo sus límites son difuminados frente a una

39 https://commons.wikimedia.org/wiki/File:Caspar_David_Friedrich_-_Der_M\%C3\%B6nch_am_Meer_Google_Art_Project.jpg

40 Cfr. Kant, I., Observaciones acerca del sentimiento de lo bello y de lo sublime, Madrid, Alianza, 2017, Sección primera y segunda.

${ }^{41}$ Cfr. Burke, E., Indagación filosófica sobre el origen de nuestras ideas acerca de lo sublime y de lo bello, Madrid, Alianza, 2014, Parte segunda. 
totalidad que le sobrepasa. La tendencia en lo sublime sería "aórgica": hacia lo informe, mediante la superación de lo particular y de individualidad de la propia conciencia. Hölderlin explora los límites de la propia subjetividad y la posibilidad de la superación de estos a partir de una experiencia estética. Si bien podemos inferir estas concepciones a partir la lectura del poeta, algunas obras de C. D. Friedrich nos permiten experimentar dichas concepciones a partir de un medio plástico. El pintor alemán materializa pictóricamente lo sublime, logrando una elevada potencia representativa que se complementa con la obra hölderliniana.

La obra de C. D. Friedrich no solo aúna en su pintura una especial afinidad temática con la obra de Hölderlin, sino que algunas de sus obras más conocidas parecen dar forma a los protagonistas de la literatura del poeta alemán -esos sujetos en diálogo dinámico con la naturaleza, entendida como manifestación de lo divino-. Hiperión representaría el sujeto romántico insatisfecho y ávido de excelsitud, aquel que persigue la infinitud en un perpetuo devenir. Friedrich habría conseguido captar dicha subjetividad errante y dotarla de una imagen en su obra El caminante sobre mar de nubes. Por otro lado, el "holocausto" empédocleo, consumado debido a la soledad y aislamiento, estaría contenido en otra de las obras más representativas de este pintor: Monje a la orilla del mar. Si en el Empédocles hemos visto representada literariamente la caída desde lo divino hasta la disolución en el abismo, estos dos cuadros representan respectivamente esos dos momentos propios de la subjetividad trágica en el Romanticismo: altura y profundidad, el "Éter" y el "abismo".

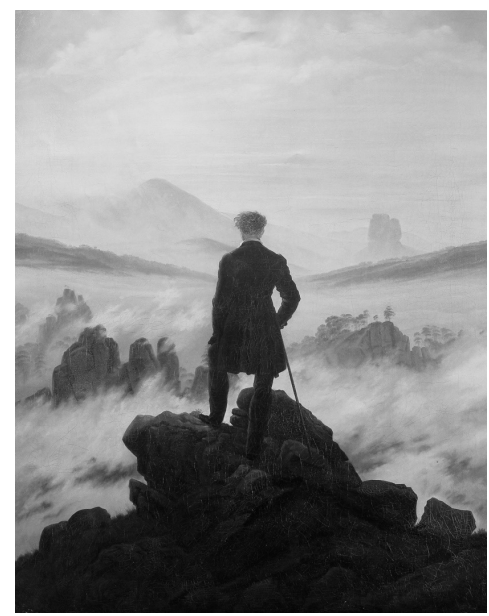

C. D. Friedrich, El caminante sobre el mar de nubes $(1818)^{42}$

El Wanderer friedricheano, ese viajero intrépido que posa su mirada sobre una naturaleza velada por una niebla de misterio y promesas, es sustituido en Monje a la orilla del mar por una figura empequeñecida y descentralizada. Es en esta obra donde se advierte de forma especialmente acusada la afinidad existente entre poeta y pintor respecto a lo trágico. La naturaleza se yergue sobre este monje en todo su terrorífico esplendor, invirtiendo la proporción entre el hombre y el paisaje que encontramos en el primer cuadro: aquí el sujeto que contempla es insignificante frente al medio natural. Esta figura contemplativa difiere del peregrino en su

42 https://commons.wikimedia.org/wiki/File:Caspar_David_Friedrich_-_Wanderer_above_the_sea_of_fog.jpg 
naturaleza: en el monje prima lo espiritual, frente a la acción y la aventura, este representa una vocación acostumbrada al recogimiento. Aquí la figura humana se halla completamente expuesta, cara a cara con dos superficies inconmensurables, celeste y marina, condensadas cromáticamente en su convergencia en el horizonte. En la unión entre cielo y mar, Friedrich logra un foco de oscuridad que destaca y atrae irresistiblemente la mirada del espectador. Mediante la concentración de materia pictórica, el pintor reclama nuestra mirada y la hace coincidir con la del monje. Experimentamos de este modo ese abismo que se abre ante él, mientras nos preguntamos por su experiencia particular; nos preguntamos qué siente. Podemos como espectadores proyectarnos hacia una costa, tratar de imaginarnos ante ese cielo y ese mar cargados de promesas de tormenta, pero no es esto lo que realmente provoca (wirken) ${ }^{43}$ el cuadro. La representación vacila entre la realidad y el sueño. La disolución formal que se atisba en el paisaje y el individuo que lo puebla dotan este paisaje de un carácter irreal, onírico, entre el ser y el no-ser. No sentimos el sonido del mar o la brisa marina, solo experimentamos un silencio abrumador y una desolación ilimitada, la nada. Esta aparente contradicción entre realidad representada y sensación provocada en el cuadro es expresada por el poeta romántico Kleist, que la vincula a la muerte:

En una soledad infinita, en la orilla, es hermoso avizorar bajo el cielo turbio un ilimitado desierto marino. [...] ante el cuadro es esto imposible, y lo que yo mismo debía encontrar en el cuadro, lo encontraba entre mí y el cuadro, y esto era una exigencia de mi corazón al cuadro y un perjuicio que el cuadro causaba en mi corazón. Era así yo mismo el capuchino y era el cuadro la duna; pero aquello que yo debía mirar con anhelo no estaba: el mar. Nada puede ser más triste y más precario que esta posición en el mundo: una única chispa de vida en el imperio de la muerte, el solitario punto medio del círculo solo. ${ }^{44}$

La inconmensurable e impertérrita naturaleza vacía de todo contenido, el protagonismo del Wanderer y la promesa que guardaba ese mar de nubes se torna en presencia de la nada. La experiencia de la nada de Hiperión y la tragedia de Empédocles encuentran aquí su correlato pictórico: la palabra "mortalmente fáctica" es traducida a una pintura metafísicamente nihilizadora. Friedrich consuma así la "tragedia del paisaje" que le atribuyó David D’Angers ${ }^{45}$, una pintura constitutivamente trágica que recoge las tensiones entre individuo y naturaleza, sujeto y objeto, finito e infinito. De igual modo que Hölderlin logra en su Hiperión una literatura idealista en la que verter su trágica sensibilidad romántica ${ }^{46}$, Friedrich desarrolla en una vertiente de su

43 "El efecto o, hablando en alemán, la Wirkung de un cuadro, testifica mucho a su favor, siempre que el efecto se proponga la verdad y la verdad atienda a la nobleza. Si el cuadro opera anímicamente en el espectador [...] ha satisfecho esa primera exigencia de toda obra de arte. [...] Cuando un cuadro deja frío y sin emoción alguna el corazón de un espectador impresionado, por mucho que sea ejemplar en la forma y el color, no puede reclamar el nombre de una verdadera obra de arte; en todo caso, el de una bella artesanía. Una obra de arte, empero, aúna ambas cosas en sí." Friedrich, C. D., citado en Hölderlin, F., Novalis, Schiller, F., et al., Fragmentos para una teoría romántica del arte, Javier Arnaldo antología y edición, Madrid, Tecnos, 2014, p. 163.

44 Kleist, H., citado en Ibidem, pp. 129-130.

45 "Voilà un homme qui a découvert la tragédie du paysage" citado en Koerner, J. L., Caspar David Friedrich and the subject of landscape, London, Reaction Books, 2009, p. 86.

46 "Hiperión representa la novela del idealismo alemán, es la expresión literaria de los contenidos filosóficos idealistas”. Cfr. Romero de Solís, D., Poíesis. Sobre las relaciones entre filosofía y poesía desde el alma trágica, Madrid, Taurus, 1981, p. 271. 
obra una pintura idealista con la que expresar en toda su majestuosidad lo sublime y su vinculación con el paisaje, lo trágico y la muerte.

Estos elementos presentes en la obra de Friedrich se hallan inter-relacionados, pues la negación de la subjetividad mediante su disolución, es decir, aquellas tendencias a la aniquilación propias del Romanticismo, coinciden con el interés por la muerte en el arte. La obra trágica de Friedrich está ampliamente transida por la muerte: se ha especulado acerca de la posibilidad de que Monje a la orilla del mar sea un autorretrato del artista $^{47}$, y también se ha insinuado que Abadía en el robledal, pareja del cuadro anterior, sería otro peculiar autorretrato. En este segundo caso nos hallaríamos ante una representación de la muerte del artista, que yace en el féretro con el que cargan los religiosos del cuadro. La subjetividad romántica expresa y representa aquí la cara más oscura de la vida, incluyendo la experiencia de la propia muerte. Una vivencia que claramente no es susceptible de ser representada por el propio pintor más que simbólicamente: es un imposible autorretrato del dejar de ser del artista. En cualquier caso, vida y obra se fusionan en la sensibilidad romántica: la biografía de Friedrich está esencialmente ligada a la experiencia de la muerte ${ }^{48}$ y la soledad. El propio Friedrich así lo confiesa, en consonancia con el leitmotiv de la muerte que engendra vida:

¿Por qué, la pregunta me asalta con frecuencia,

Eliges como objeto de la pintura

Tantas veces la muerte, la caducidad y el sepulcro?

Para llegar a vivir eternamente algún día,

hay que entregarse a la muerte asiduamente. ${ }^{49}$

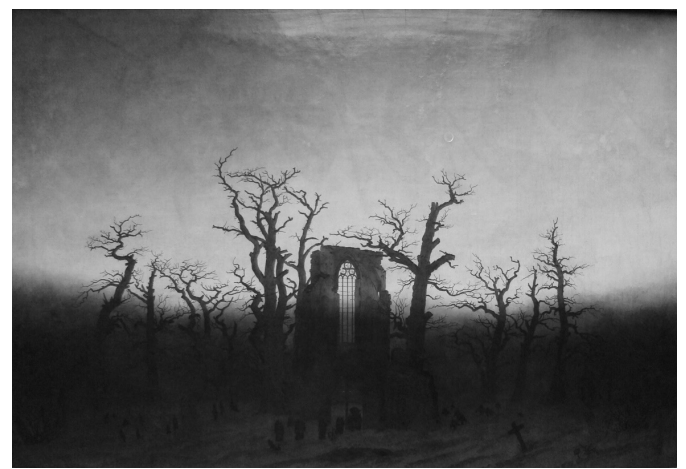

C. D. Friedrich, Abadia en el robledal (1809) $)^{50}$

47 Jensen, J. C., Caspar David Friedrich: vida y obra, Barcelona, Blume, 1980, p. 108.

48 En su biografía destaca el momento en que su hermano desapareció bajo el hielo de un lago, frente a los ojos del pintor. Este episodio le perseguirá por siempre y según algunos testimonios fue causa de varios intentos de suicidio por parte del pintor. Cfr. Ibidem, p. 111. La melancolía y la presencia de la muerte es compartida por Hölderlin, quien presenció cómo fallecían su padre, su padrastro y varios de sus hermanos durante su infancia y juventud. Cfr. Cortés Gabaudan, H., La vida en verso. Biografía poética de Friedrich Hölderlin, Madrid, Hiperión, 2014, págs. 22, 71.

49 Citado en Jensen, J. C., Caspar David Friedrich: vida y obra, op. cit., p. 115.

$50 \mathrm{https} / / /$ commons.wikimedia.org/wiki/File:Caspar_David_Friedrich_-_Abtei_im_Eichwald_-_Google_Art_ Project.jpg 


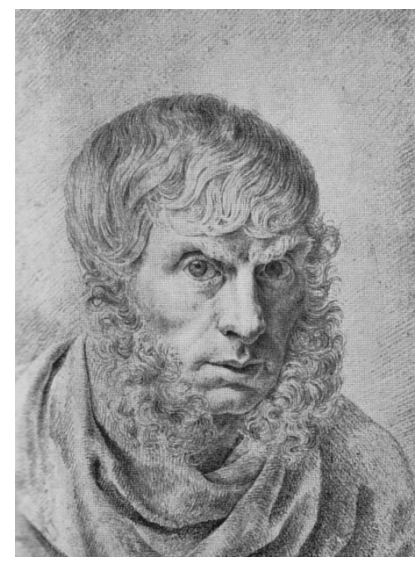

C. D. Friedrich, Autorretrato (c. 1810) $)^{51}$

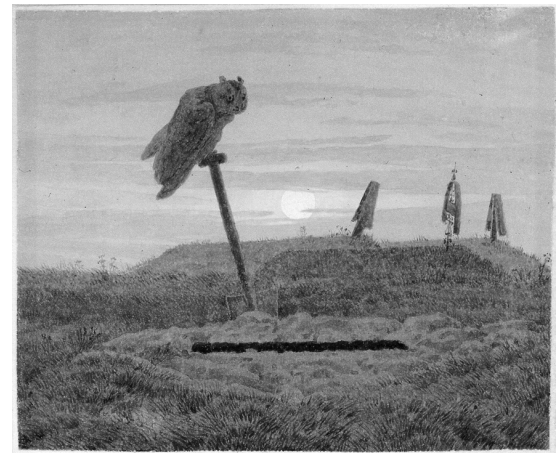

C. D. Friedrich, Búho sobre una tumba (post. a 1837) ${ }^{52}$

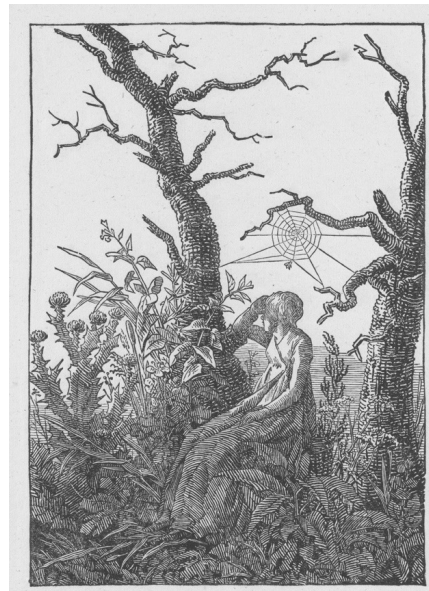

C. D. Friedrich, Melancolía $(1801-17)^{53}$

${ }_{51}$ https://commons.wikimedia.org/wiki/File:Caspar_David_Friedrich_self_portrait.jpeg

52 https://commons.wikimedia.org/wiki/File:Caspar_David_Friedrich_-_Eule_am_Grabe.jpg

53 https://commons.wikimedia.org/wiki/File:Seated_Woman_with_a $\overline{\text { S Spider}} \% 2 \overline{7} \mathrm{~s}$ _Web_(Die_Frau_mit_dem_ 
La experiencia de la muerte aparece profusamente en la obra de Friedrich. Según el autor, su objetivo sería, tal y como acabamos de citar, "llegar a vivir eternamente algún día". Es decir, nuevamente aquí la muerte no se representa exclusivamente por su interés, sino por su relación con la vida y la creación, una relación entendida por Friedrich en términos eminentemente religiosos ${ }^{54}$. Estas oposiciones -creacióndestrucción, vida-muerte- forman parte de la condición existencial trágica descrita en la obra de Hölderlin. En el caso de Friedrich, dichas oposiciones aparecen ligadas a su profunda fe religiosa.

Además de la muerte, existe otro elemento de igual relevancia en las obras del pintor, cuyas raíces son también biográficas y provienen de la vivencia existencial del artista: el silencio. Más arriba se ha expuesto el desarrollo de Hölderlin sobre este mismo elemento de índole sensible y simbología trágica ${ }^{55}$, especialmente en su obra La muerte de Empédocles. La experiencia del silencio tiene una presencia aún mayor que la de la muerte en la obra del pintor. Un silencio que Friedrich vivió consciente y profundamente ${ }^{56}$ y por ello seguramente fue capaz de trasladarlo de modo tan vivo a sus obras. Este silencio, vínculo representativo y existencial entre poeta y pintor, es constitutivo en las obras de Friedrich, dando lugar a diversas representaciones del mismo: un silencio físico y otro metafísico. El primero lo encontramos en $E l$ caminante sobre el mar de nubes, en ese páramo de roca desnuda elevado sobre toda vida vegetal y animal -incluyendo su sonido-, una altura solo al alcance del ser humano y sus capacidades. Podemos imaginarnos escuchando únicamente el sonido de la respiración del peregrino, exhausto tras su ascensión. Este silencio físico comparece también en El mar de hielo, un cuadro vinculado temáticamente con los dos que hemos comentado, en el que la presencia del barco naufragado es eclipsada por el desmesurado bloque de hielo que protagoniza la imagen. Aquí ni siquiera lo humano tiene cabida, ni tan siquiera la muerte como naufragio es protagonista: todo es silencio en ese páramo helado y muerto. Esta experiencia difiere respecto al silencio metafísico de Monje a la orilla del mar. En esta ocasión no 'escuchamos' porque no hay nada que escuchar, el universo permanece callado porque adolece de voz propia. Más aún, nuestra voz interior permanece silente ante el espectáculo de lo sublime y la presencia aniquiladora de la nada.

Spinnennnetz_zwischen_kahlen_Baumen)_MET_DP872947.jpg

54 Ejemplo de ello sería su conocido cuadro, el altar de Tetschen. La concepción de la naturaleza como manifestación de Dios y, por ello, también como elemento religioso, se materializan de forma cristalina en esta obra, cuyo paisaje estaba destinado a situarse como altar.

55 El silencio es aislamiento, como bien expresa Hölderlin. La armonía y la consonancia expresan vínculo. En el silencio uno queda aislado sobre su propia voz interior; palabra, pero no sonido. Son profundas metáforas de índole sensible -nótese que la relevancia de lo estético es absoluta- sobre la subjetividad y la intersubjetividad. El silencio se vincula en La muerte de Empédocles también a la muerte y la soledad. Como contraparte positiva, Hölderlin desarrollaría toda una plétora metafórica sobre la música y la relación entre voces, consonante y disonante.

56 "Todo es silencio $[\ldots]$ a mi alrededor; $[\ldots]$ me hace mucho bien, pero quisiera no tenerlo en torno a mí en tan alto grado [...] solo y siempre solo" citado en Jensen, J. C., Caspar David Friedrich: vida y obra, op. cit., p. 153. 


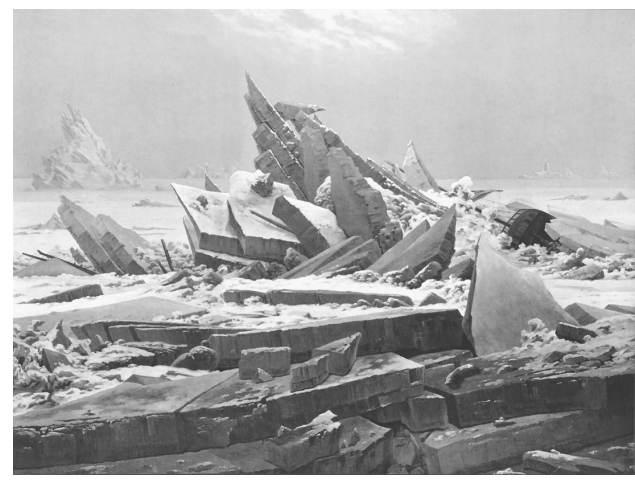

C. D. Friedrich, El mar de hielo $(1823-24)^{57}$

Muerte y silencio conforman buena parte de la experiencia del universo y la naturaleza en la obra romántica de Friedrich, pero falta un tercer elemento constitutivo de esa cara oscura y trágica presente en algunas sensibilidades románticas: la melancolía y su instancia particular y específicamente romántica, el Weltschmerz. Diferentes grados de esta melancolía acompañan a los silencios físico y metafísico y la experiencia de la muerte en la pintura de Friedrich. El pintor no solo comunica "una experiencia muda del horizonte" 58 , sino que convierte al horizonte en representación plástica del diálogo interno del artista con el infinito. Este diálogo expresa en ocasiones un estado melancólico que acompaña a un sentimiento extático, tal y como sucede en El caminante sobre el mar de nubes. Sin embargo, esta melancolía difiere en el caso de El mar de hielo, pues se torna en terror ante la indiferencia de una naturaleza poblada de aristas en la que la travesía vital humana no tiene cabida: el naufragio y la muerte son el desenlace del viaje ${ }^{59}$. Friedrich da un paso más en Monje a la orilla del mar, mostrando el Weltschmerz romántico en su esplendorosa plenitud. La melancolía adopta en su deriva romántica una consistencia y un peso que jamás había tenido: inconmensurable e indenifible ${ }^{60}$, la melancolía se extiende sin límite en el tiempo. Friedrich consigue en su obra diluir este sentimiento, "en un anhelo profundo, sin objeto ni dirección, de algo desconocido" ${ }^{61}$.

Estos tres cuadros quedan unidos por una experiencia melancólica in crescendo del silencio y por su representación, que utiliza el paisaje marino como materialización plástica. Efectivamente, las tres imágenes tienen, además de la melancolía en sus diferentes grados, ese correlato plástico descrito por Argullol como el "espejo cósmico de una melancolía totalizadora" ${ }^{62}$ : el mar. Este no solo permite reflejar sobre sí esa "melancolía totalizadora", sino que reúne los requisitos descritos por Burke para invocar con su representación el sentimiento de lo sublime. El mar es percibido

57 https://commons.wikimedia.org/wiki/File:Caspar_David_Friedrich_-_Das_Eismeer_-_Hamburger Kunsthalle_-_02.jpg

58 Corbin, A., Historia del silencio. Del Renacimiento hasta nuestros días, Barcelona, Acantilado, 2019 , p. 90.

59 Molinuevo, J. L., Estéticas del naufragio y de la resistencia, Valencia, Institució Alfons el Magnànim Diputació de València, 2001, pp. 9 y ss.

60 Klibansky, R., Panofsky, E., Saxl. F., Saturno y la melancolía, Madrid, Alianza, 2016, pp. 235-237.

${ }^{61}$ Ibidem, pp. 370-371. Si bien Friedrich comprendía su obra como orientada hacia lo divino en su manifestación del mundo natural, como espectadores de Monje a la orilla del mar este objeto al que dirigir el Weltschmerz resulta difícilmente identificable. Percibimos ausencia, no presencia.

62 Argullol, R., La atracción del abismo. Un itinerario por el paisaje romántico, op. cit., p. 89. 
como infinito en su perderse en el horizonte y en la extrema vastedad de su superficie. Representa también el abismo, pues además de extenderse infinitamente en el horizonte, su fondo tampoco parece tener fin: nos lo imaginamos como un oscuro abismo en el que caer. Sentimos un doble infinito a causa de la imposibilidad de aprehender su límite en extensión o profundidad con nuestras facultades, únicamente nuestra imaginación puede intentar lidiar con lo ilimitado.

El paisaje marino no solo es susceptible de ser un objeto que cause el sentimiento de lo sublime, sino que guarda una estrecha relación simbólica con las reflexiones románticas que hemos presentado sobre la naturaleza. Esta imagen del mar alberga en sí la esencia trágica del Romanticismo, pues es una unidad que no podemos abarcar, una manifestación de la soberbia fuerza natural en la que sentimos nuestra finitud, limitación e impotencia. Podemos intentar navegar sus aguas flotando en su superficie cambiante, mas nunca acogerá al ser humano de forma permanente, pues es un espacio obligado de itinerancia. El mar se presenta como un lugar en el que solo cabe la inestabilidad y la errancia, en el que el ser humano siente su devenir en manos de fuerzas desconocidas que le superan, pero al mismo tiempo le fascinan.

Esta imagen marina no solo está presente en los cuadros de Friedrich, sino que es recurrente en la poesía de Hölderlin. Este desarrolló una "poética fluvial"63 en la que el artista se representa a sí mismo como un río, en la medida que el poeta va ejerciendo esa labor educativa a su paso, análoga a la fertilización de los campos bañados por las aguas fluviales. Esta imagen fluvial muestra un carácter errante, pero ligado a un destino: proveer de vida a los pueblos que disponen de su cauce antes de desembocar en el mar; es decir, iluminar la sociedad mediante la poesía antes de que la tragedia, el nefas y la disolución arrastren al poeta hacia el abismo. El poeta se vincula al río en tanto que este está abocado a disolverse en el abismo del mar: las fuerzas de la naturaleza convocan inevitablemente a cada río y sus dulces aguas a su desembocadura en el Todo salino. Esa misma "nostalgia de abismo" al artista desde el momento de su nacimiento y eclosiona en el instante en el que emerge la conciencia y con ella toda escisión y oposición -la realidad de la finitud y la muerte-. La conciencia del poeta se siente atraída por la disolución en el Todo, representado aquí por el mar, esa entidad natural dinámica y llena de vida, pero también de peligro y muerte para el ser humano.

El mar es lugar de disolución y pérdida de la naturaleza 'particular' de los ríos, pero también propicia la génesis y el retorno de los ríos a sus cauces a través de la lluvia. Esta renovación continua y la contraposición entre totalidad y particularidad es una de las ideas románticas que hemos desarrollado en este trabajo, como veíamos en El devenir en el perecer. El contenido filosófico de este texto de Hölderlin despliega posibilidades plásticas muy sugerentes a la luz de la imagen fluvial, y también marina. El mar es un todo, pero con sus individuaciones: el dinamismo del mar se particulariza con la continua producción de oleaje, olas que devienen y perecen constantemente. El sujeto lírico se fluidifica en su identificación con esta doble imagen acuosa e incide en su participación del proceso permanente de ocaso y génesis natural, reforzando ese carácter en devenir de la subjetividad romántica.

El paisaje marino y la imagen fluvial ofrecen un correlato plástico a la constelación de ideas románticas en torno al yo trágico presentadas en este trabajo:

Cortés Gabaudan, H., La vida en verso. Biografía poética de Friedrich Hölderlin, op. cit., p. 38 n. 22.

${ }_{64}$ La voz del pueblo / Stimme des Volks en Hölderlin, F., Poesía esencial, Madrid, La Oficina, 2017, pp. 48-49. 
la aspiración por alcanzar la esfera de la divinidad se enfrenta con una naturaleza ambigua, en ocasiones armónica y vibrante, en otras ocasiones silente y ajena. Este carácter ambiguo queda reflejado en las obras de Hölderlin y Friedrich: el Wanderer de Friedrich y el Hiperión de Hölderlin obtienen su reverso en las figuras del monje y de Empédocles. La errancia romántica a través de una naturaleza poblada de belleza deviene en un exceso de movimiento representado por la disolución formal ante lo sublime, la profusa temática de la muerte y la autodestrucción, así como la fluidificación metafórica del Yo lírico. El sujeto romántico es sometido a una continua tensión entre extremos que no puede conjugar y que crean un dinamismo de tal espectro que difícilmente es abarcable por el ser humano. Ni tan siquiera los individuos más excepcionales - los denominados genios- serán finalmente capaces de apresar el fuego prometeico que ilumina, pero también abrasa, su sensibilidad.

\section{Conclusión}

En definitiva, la subjetividad se presenta en estos autores particularmente ligada a una existencia en tensión. Este esfuerzo por representar lo trágico en su carácter ilimitado e irreconciliable se ve acompañado por una tensión extrema a la que son sometidas las subjetividades románticas descritas en el presente trabajo. Dicha tensión y el dinamismo que de ella se desprende se deben principalmente a esa tendencia "aórgica" descrita en el Empédocles, cuyo correlato plástico sería lo sublime pictórico representado en ciertas obras de Friedrich. La relación entre individuo y naturaleza es elaborada idealmente a partir de este ambiente de oposición entre lo finito e infinito, dando cuerpo al sentimiento trágico del sujeto. Ello es patente tanto en la literatura de Hölderlin -en Hiperión y en Empédocles, la naturaleza, en su carácter de totalidad panteísta, cumple un papel esencial- como en la obra de Friedrich, una pintura eminentemente paisajística. En el caso del poeta es posible estudiar la subjetividad romántica a través de su recreación literaria, mientras que Friedrich comparte con algunos de sus cuadros estados afectivos concretos, en los que el sujeto mantiene una doble relación con el paisaje: por un lado, esta es una totalidad ante la que se sitúa; por otro lado, la naturaleza es una instancia especular de la propia subjetividad.

Hölderlin y Friedrich se esfuerzan por materializar artísticamente esta subjetividad en conflicto, sea de forma literaria o pictórica, logrando crear una serie de manifestaciones materiales y particulares de lo trágico. Las representaciones trágicas analizadas muestran cómo dicho espíritu trágico permea tanto su reflexión como su creación artística. El poeta y el pintor acuden a elementos comunes -el silencio, la melancolía, la muerte y la imaginería marino-fluvial- con el fin de expresar un sentimiento y generarlo en sus espectadores. La obra de ambos autores apela a la esfera afectiva de quien la lee o la contempla, pero no es su objetivo limitarse a dicha esfera, pues este sentimiento trágico está dotado de relevancia filosófica.

Es en dicho conflicto donde acontece lo "originario" según Hölderlin o, dicho en otras palabras, el conflicto trágico es un medio hacia la autoconciencia mediada por la intuición intelectual. Pese a que Friedrich no tematiza expresamente reflexiones similares, su pintura trágica se enmarca claramente bajo una misma concepción del arte y del artista. Asimismo, la relación entre individuo y naturaleza-divinidad resulta afín a la hölderliniana, aunque el trasfondo religioso sea diverso. Las pinturas 
de Friedrich ofrecen de este modo un campo de estudio complementario al corpus del poeta en lo que al sujeto trágico se refiere, cuyo genio artístico y especial sensibilidad abren una vía hacia su aniquilación. El pintor ofrece en los cuadros descritos la representación del momento concreto en el que su protagonista siente en profundidad el "Éter" y el "abismo", transmitiendo con ello al espectador el peso de su existencia trágica.

Friedrich Hölderlin y Caspar David Friedrich convierten la palabra y la imagen en medios con los que representar un sentimiento trágico, en un espejo en el que reflejarse y al mismo tiempo negarse en su individualidad, sea a partir de la búsqueda hölderliniana de un continente literario extraño o mediante las figuras friedrichianas sin rostro. Pintor y poeta trabajan una subjetividad que se repliega sobre sus conflictos interiores -intelectuales, vitales y religiosos-, pero que no por ello abandona su aspiración a lo universal, pues lo trágico deviene condición existencial.

\section{Referencias bibliográficas}

Argullol, R., El Héroe y el Único, Barcelona, Acantilado, 2008.

Argullol, R., La atracción del abismo. Un itinerario por el paisaje romántico, Barcelona, Acantilado, 2006.

Bernabé, A., Fragmentos presocráticos, Madrid, Abada, 2019.

Burke, E., Indagación filosófica sobre el origen de nuestras ideas acerca de lo sublime y de lo bello, Madrid, Alianza, 2014.

Corbin, A., Historia del silencio. Del Renacimiento hasta nuestros días, Barcelona, Acantilado, 2019.

Cortés Gabaudan, H., La vida en verso. Biografía poética de Friedrich Hölderlin, Madrid, Hiperión, 2014.

Garelli, G., Gentilli C., Lo trágico, Madrid, Machado, 2015.

Hölderlin, F., Correspondencia completa, Madrid, Hiperión, 1990.

Hölderlin, F., Ensayos, Madrid, Hiperión, 2017.

Hölderlin, F., Hiperión o el eremita en Grecia, Madrid, Hiperión, 2017.

Hölderlin, F., Poesía esencial, Madrid, La Oficina, 2017.

Hölderlin, F., La muerte de Empédocles, Barcelona, Acantilado, 2001.

Hölderlin, F., Novalis, Schiller, F., et al., Fragmentos para una teoría romántica del arte, Javier Arnaldo antología y edición, Madrid, Tecnos, 2014.

Hölderlin, Sófocles, Antígona, prólogo de Arturo Leyte Coello, edición bilingüe y traducción de Helena Cortés Gabaudan y Manuel Enrique Prado Cueva, Madrid, La Oficina, 2012.

Hölderlin, Sófocles, Edipo, prólogo de Arturo Leyte Coello, edición trilingüe y traducción de Helena Cortés Gabaudan, Madrid, La Oficina, 2014.

Jensen, J. C., Caspar David Friedrich: vida y obra, Barcelona, Blume, 1980.

Kant, I., Observaciones acerca del sentimiento de lo bello y de lo sublime, Madrid, Alianza, 2017.

Klibansky, R., Panofsky, E., Saxl. F., Saturno y la melancolía, Madrid, Alianza, 2016.

Koerner, J. L., Caspar David Friedrich and the subject of landscape, London, Reaction Books, 2009.

Molinuevo, J. L., Estéticas del naufragio y de la resistencia, Valencia, Institució Alfons el Magnànim - Diputació de València, 2001. 
Romero de Solís, D., Poíesis. Sobre las relaciones entre filosofía y poesía desde el alma trágica, Madrid, Taurus, 1981.

Waterfield, R., The first philosophers. The presocratics and the sophists, New York, Oxford University Press, 2000.

\section{Imágenes}

C. D. Friedrich, Monje a la orilla del mar (1808-1810)

https://commons.wikimedia.org/wiki/File:Caspar_David_Friedrich_Der_M\%C3\%B6nch_ am_Meer_-_Google_Art_Project.jpg

C. D. Friedrich, El caminante sobre el mar de nubes (1818)

https://commons.wikimedia.org/wiki/File:Caspar_David_Friedrich_Wanderer_above_the_ sea_of_fog.jpg

C. D. Friedrich, Abadía en el robledal (1809)

https://commons.wikimedia.org/wiki/File:Caspar_David_Friedrich_Abtei_im_ Eichwald_-_Google_Art_Project.jpg

C. D. Friedrich, Autorretrato (c. 1810)

https://commons.wikimedia.org/wiki/File:Caspar David Friedrich self portrait.jpeg

Friedrich, Búho sobre una tumba (post. a 1837)

https://commons.wikimedia.org/wiki/File:Caspar_David_Friedrich_Eule_am_Grabe.jpg

C. D. Friedrich, Melancolía (1801-17)

https://commons.wikimedia.org/wiki/File:Seated Woman with a Spider\%27s Web (Die

Frau_mit_dem_Spinnennnetz_zwischen_kahlen_Baumen)_MET_DP872947.jpg

C. D. Friedrich, El mar de hielo (1823-24)

https://commons.wikimedia.org/wiki/File:Caspar_David_Friedrich_-_Das_Eismeer_-_ Hamburger_Kunsthalle_-_02.jpg 